\title{
Hepatoprotective Effect of an Antrodia cinnamomea Product Via a Novel Process on Carbon Tetrachloride-Induced Hepatotoxicity in Rats
}

\author{
Hong-Ying Hsiao, Yih-Ming Weng* \\ Department of Food Science, National Chiayi University, Chiayi, Taiwan \\ Email address: \\ karen0933@qq.com (Hong-Ying Hsiao), ymweng@mail.ncyu.edu.tw (Yih-Ming Weng) \\ ${ }^{*}$ Corresponding author
}

\section{To cite this article:}

Hong-Ying Hsiao, Yih-Ming Weng. Hepatoprotective Effect of an Antrodia cinnamomea Product Via a Novel Process on Carbon Tetrachloride-Induced Hepatotoxicity in Rats. International Journal of Nutrition and Food Sciences. Vol. 7, No. 4, 2018, pp. $134-141$. doi: $10.11648 /$ j.ijnfs.20180704.14

Received: June 17, 2018; Accepted: August 2, 2018; Published: August 13, 2018

\begin{abstract}
Antrodia cinnamomea, causing a brown heart rot of Cinnamomum kanehirai Hay. endemic to Taiwan, was reported to have several biological activities for treating liver diseases, inflammation, tumors, et al. It was believed that wild or wood-cultured A.cinnamomea on C.kanehirai Hay. was better than by other means. However, C.kanehirai Hay. was rare and expensive, that resulted in a higher price of wild or wood-cultured A.cinnamomea. Hence, a novel process was developed to spray solid-state-cultured A.cinnamomea extracts on wood-cultured A.cinnamomea powder to make a high quality and low price product. The purpose of the study was to evaluate its hepatoprotection against carbon tetrachloride-induced hepatotoxicity in rats. Results revealed that aspartate aminotransferase (AST) and alanine aminotransferase (ALT) of Sprague Dawley rats administered $20 \%$ carbon tetrachloride $\left(\mathrm{CCl}_{4}\right)$ twice a week, when the rats was also administered $413.4 \mathrm{or} 1033.5 \mathrm{mg} / \mathrm{kg}$ body weight (BW) A.cinnamomea daily for 8 weeks, were significantly reduced in serum. Administration of $1033.5 \mathrm{mg} / \mathrm{kg} \mathrm{BW}$ A.cinnamomea daily would not only reduce the rats' liver and spleen swelling, liver fibrosis, and level of hydroxyproline, but increase activities of superoxide dismutase, catalase, glutathione peroxidase, glutathione reductase, and glutathione. In conclusion, the A.cinnamomea product via the novel process at $1033.5 \mathrm{mg} / \mathrm{kg} \mathrm{BW}$ had hepatoprotective effects on carbon tetrachloride-induced hepatotoxicity in rats.
\end{abstract}

Keywords: Antrodia cinnamomea, Hepatoprotection, Novel Process, Carbon Tetrachloride

\section{Introduction}

The chronic liver diseases and cirrhosis was one of the ten leading causes of death in Taiwan [1]. In the worldwide, liver cirrhosis was ranked $23^{\text {rd }}$ according to a systematic analysis for the Global Burden of Disease Study 2010 [2]. The mortality from liver cirrhosis accounted for a growing and substantial disease burden worldwide each year, and the global liver cirrhosis deaths increased from 676 thousands in 1980 to over 1 million in 2010 [3]. The etiology of liver cirrhosis varied in different countries, but either alcoholic liver disease or viral hepatitis was the commonest cause [4-6].

Antrodia cinnamomea, a polypore fungus endemic to
Taiwan, was reported to have extensive biological activity and effectiveness in treating liver injury [7]. However, studies revealed A.cinnamomea products from different cultivation had different effects on inhibition of human hepatoma cell proliferation [8, 9], inhibition of inducible nitric oxide synthase expression [10], and antioxidant activities [9], and the solid-state-cultured A.cinnamomea had more effectiveness than the liquid-state-cultured one $[8,10]$. Wild and wood-cultured A.cinnamomea products were rarely discussed because of expensive cost and rareness of Cinnamomum kanehirai Hayata, but it was believed that the wild and wood-cultured A.cinnamomea products were more 
effectiveness in general.

Hence, a novel process was developed in the study to spray solid-state-cultured A.cinnamomea extracts on wood-cultured A.cinnamomea powder to make a high quality and low price product. Whether the A.cinnamomea product via the novel process had the same hepatoprotection was the purpose of the study.

\section{Material and Methods}

\subsection{Microorganism and Culturing Condition}

Antrodia cinnamomea was obtained from the Greenrays International Co., Ltd. (Chiayi, Taiwan). In solid-state-cultured condition, the mycelia were cultured using mushroom grow bags. Each bag contained corn cob, rice bran, wheat bran, and corn powder in the ratio 15.8:2.6:2.6:1 (w/w), adding $0.1 \%$ magnesium sulfate $\left(\mathrm{MgSO}_{4}\right)$ and $0.1 \%$ zinc sulfate $\left(\mathrm{ZnSO}_{4}\right)$, with water content of $53.94 \%$. After sterilizing by autoclaving at $120^{\circ} \mathrm{C}$ for 2 hours, the bag was cooled down to $20^{\circ} \mathrm{C}$ and then inoculated with the mycelia. After cultivation at $25^{\circ} \mathrm{C}$ for 3 months, the grow bag was removed and reverse osmosis water was sprayed to induce primordia. The fruiting bodies were selected and harvested after 6 months, and the harvested mycelia with substrates were dried with air and were crushed. In wood-cultured condition, stout camphor (Cinnamomum kanehirai Hayata) trunks were inoculated with the mycelia and were placed in growth chambers equipped with a Supa Fine HF-096 cool mist humidifier (Shivn Feng Enterprise Co., Ltd., New Taipei City, Taiwan) running at 7-9 AM and 8-9 PM. The fruiting bodies were selected and harvested after 6 months. The solid-state-cultured and wood-cultured fruiting bodies both were dried and were powdered into 100 150 meshes.

\subsection{Extraction, Concentration, and Spray Granulation}

Six hundred kilograms powder of mycelia with substrates was extracted 3 different extraction solvents. First, the powder was extracted with $6,000 \mathrm{~kg}$ of $55 \%$ ethanol at $50^{\circ} \mathrm{C}$ for 18 hours. Second, the filter residue was extracted with $6,000 \mathrm{~kg}$ of reverse osmosis water at $90^{\circ} \mathrm{C}$ for 18 hours. Finally, the second filter residue was extracted with $6,000 \mathrm{~kg}$ of reverse osmosis water under high pressure at $120^{\circ} \mathrm{C}$ for 18 hours. These three filtrates were then concentrated separately under vacuum at $45-55^{\circ} \mathrm{C}$ [11]. The concentrates were used for spray-drying granulation with the powdered fruiting bodies as starter cores at 65 $70^{\circ} \mathrm{C}$ in reversed order, and thereafter powdered into 100 meshes again.

\subsection{Animal Experiment}

Sixty male Sprague Dawley rats aged 7-8 weeks were purchased from BioLASCO Taiwan Co., Ltd. (Taipei, Taiwan) and tested in Super Laboratory Co., Ltd. (New Taipei City, Taiwan). Two rats in each cage were grown under a 12-h light/dark cycle at $22 \pm 3^{\circ} \mathrm{C}$ and relative humidity of $55 \pm 15 \%$. The rats were given ad libitum access to food and reverse osmosis water. After one-week acclimation and quarantine period, they were randomly divided into six groups: (1) Control group, olive oil + reverse osmosis water; (2) RO group, $20 \% \mathrm{CCl}_{4}+$ reverse osmosis water; (3) Silymarin group, $20 \% \mathrm{CCl}_{4}+20 \mathrm{mg} / \mathrm{mL}$ silymarin solution; (4) AC2067 group, $20 \% \mathrm{CCl}_{4}+20.67 \mathrm{mg} / \mathrm{mL}$ A.cinnamomea solution; (5) AC4134 group, $20 \% \mathrm{CCl}_{4}+$ $41.34 \mathrm{mg} / \mathrm{mL}$ A.cinnamomea solution; (6) AC10335 group, $20 \% \mathrm{CCl}_{4}+103.35 \mathrm{mg} / \mathrm{mL}$ A.cinnamomea solution. Two $\mathrm{mL} / \mathrm{kg}$ body weight (BW) of olive oil (solvent) or $20 \% \mathrm{CCl}_{4}$ was administered via oral gavage every Tuesday and Friday for 8 weeks, and $10 \mathrm{~mL} / \mathrm{kg} \mathrm{BW}$ of reverse osmosis water (solvent), silymarin, or A.cinnamomea solution was administered every day for 8 weeks. The doses of A.cinnamomea were 206.7, 413.4, $1033.5 \mathrm{mg} / \mathrm{kg} \mathrm{BW}$, respectively. The body weight of every rat was measured once a week while the weekly food intake was recorded. At the eighth week, carbon dioxide $\left(\mathrm{CO}_{2}\right)$ was used for the humane euthanasia of the rats. Thereafter, the liver and spleen were excised and weighed.

\subsection{Serum Biochemical Assays}

Blood samples were collected from caudal vein at the first, third, and sixth weeks, and a final blood sample was taken from the heart of rat. The serum was obtained from blood by centrifuging at $4^{\circ} \mathrm{C}$ at $3,000 \mathrm{~g}$ for $15 \mathrm{~min}$. Alanine aminotransferase (ALT) and aspartate aminotransferase (AST) were tested using the ADVIA $^{\circledR} 1800$ Clinical Chemistry System (Siemens Healthcare $\mathrm{GmbH}$, Erlangen, Germany) at the $1^{\text {st }}, 3^{\text {rd }}, 6^{\text {th }}$, and $8^{\text {th }}$ weeks. Total protein, albumin, globulin, triglyceride, and cholesterol were examined using the same equipment at the $8^{\text {th }}$ week.

\subsection{Biochemical Assays and Histology of Liver}

The liver tissue was processed according to the method of Xia et al. [12], and enzyme activities of superoxide dismutase (SOD), glutathione peroxidase (GPx), glutathione reductase (GRd) were determined using Randox kits (Randox Laboratories, Ltd., Crumlin, UK). Catalase activity was determined according to the method of Aebi [13].

The determination of glutathione (GSH) content was modified from the method of Hissin and Hilf [14]. After 0.5 $\mathrm{g}$ of liver tissue adding $5 \mathrm{~mL}$ of $1.15 \%$ potassium chloride $(\mathrm{KCl})$ was homogenized, $1 \mathrm{~mL}$ of the solution mixed with 1 $\mathrm{mL}$ of $10 \%$ trichloroacetic acid $\left(\mathrm{CCl}_{3} \mathrm{COOH}\right)$ was centrifuged at $4{ }^{\circ} \mathrm{C}$ at $3,000 \mathrm{~g}$ for $15 \mathrm{~min}$. To $0.01 \mathrm{~mL}$ of the supernatant, $0.18 \mathrm{~mL}$ of the phosphate-EDTA buffer and 0.01 $\mathrm{mg} / \mathrm{mL}$ of $\sigma$-phthalaldehyde diluted in methanol $\left(\mathrm{CH}_{3} \mathrm{OH}\right)$ were added. After thorough mixing, the glutathione (GSH) of the solution was determined at $420 \mathrm{~nm}$ with the activation at $350 \mathrm{~nm}$.

The detection of hydroxyproline in the supernatant was modified from Neuman and Logan's method [15]. The liver tissue was sliced into strips and dried at $80^{\circ} \mathrm{C}$ in an oven for 20-22 hours, and then the dried tissue was hydrolyzed by 
adding hydrochloric acid $(\mathrm{HCl})$ at $100^{\circ} \mathrm{C}$ in the oven. Thereafter, the cooled hydrolyzed sample was centrifuged. Into each test-tube containing $1 \mathrm{~mL}$ of standard or the supernatant was pipetted in succession $1 \mathrm{~mL}$ each of $0.01 \mathrm{M}$ copper sulfate $\left(\mathrm{CuSO}_{4}\right), 2.5 \mathrm{~N}$ sodium hydroxide $(\mathrm{NaOH})$, and $6 \%$ hydrogen peroxide $\left(\mathrm{H}_{2} \mathrm{O}_{2}\right)$. They were mixed and shaken by Vortex Mixer, and then placed in a water bath at $80^{\circ} \mathrm{C}$ for 5 minutes. After the tubes were chilled, $2 \mathrm{~mL}$ of 4-(dimethylamino) benzaldehyde and $4 \mathrm{~mL}$ of $3 \mathrm{~N}$ sulfuric acid $\left(\mathrm{H}_{2} \mathrm{SO}_{4}\right)$ were pipetted into the tubes in succession. The tubes were placed in a water bath at $70^{\circ} \mathrm{C}$ for $3 \mathrm{~min}$ and cooled in iced water. The detection was done at $540 \mathrm{~nm}$ using a spectrophotometer.

The liver tissue was cut into pieces and fixed in $10 \%$ formalin. The specimens were dehydrated, cleaned, penetrated with paraffin, and embedded in paraffin. The specimens were sectioned at a thickness of $5 \mu \mathrm{m}$ using a semi-motorized rotary microtome Leica RM 2145 (Leica Microsystems Nussloch GmbH, Nussloch, Germany) and stained with hematoxylin and eosin (H\&E) or sirius red. The specimens were observed using Nikon Optiphot-2 microscope (Nikon Corporation, Tokyo, Japan). Vacuolation and necrosis were semiquantitatively scored. Grade 0 represented normal, and grades 1-4 had slight to marked involvement. Fibrosis was graded as follows: grade 0, normal liver; grade 1, increase of collagen without formation of septa; grade 2, incomplete septa from portal tract to central vein; grade 3, complete but thin septa interconnecting with each other and dividing the parenchyma into separate fragments; grade 4, as grade 3, with thick septa (complete cirrhosis) [16].

\subsection{Statistical Analysis}

SAS Studio 3.4 (SAS Institute Inc., Cary, North Carolina, USA) was used for statistical analysis. The body weight, weekly food intake, ALT, and AST were analyzed and compared with the Control, RO, Silymarin, or AC2067 groups for repeated measures analysis using a mixed model. The one-way analysis of variance (ANOVA) followed by post-hoc Dunnett's test was performed for the total protein, albumin, globulin, triglyceride, cholesterol, and biochemical assays and semiquantitative assessments of liver. Statistical significance was defined as $\mathrm{p}<0.05$.

\section{Results}

\subsection{Body Weight and Food Intake}

Administration of $20 \% \mathrm{CCl}_{4} 2 \mathrm{~mL} / \mathrm{kg} \mathrm{BW}$ twice a week for 8 weeks resulted in significantly decreased food intake and body weight in the rats (Figure 1). At the $8^{\text {th }}$ week, the weekly food intake and body weight were $203.7 \pm 3.6 \mathrm{~g}$ and $436.6 \pm 23.3 \mathrm{~g}$ in the Control group and $157.7 \pm 20.5 \mathrm{~g}$ and $364.8 \pm 54.2 \mathrm{~g}$ in the RO group, respectively. Treatment with the dose of $1033.5 \mathrm{mg} / \mathrm{kg}$ BW A.cinnamomea every day slightly increased the weekly food intake and body weight to $171.3 \pm 11.1 \mathrm{~g}$ and $384.7 \pm 26.3 \mathrm{~g}$ at the $8^{\text {th }}$ week although there was no significance among the groups administered $20 \% \mathrm{CCl}_{4}$.

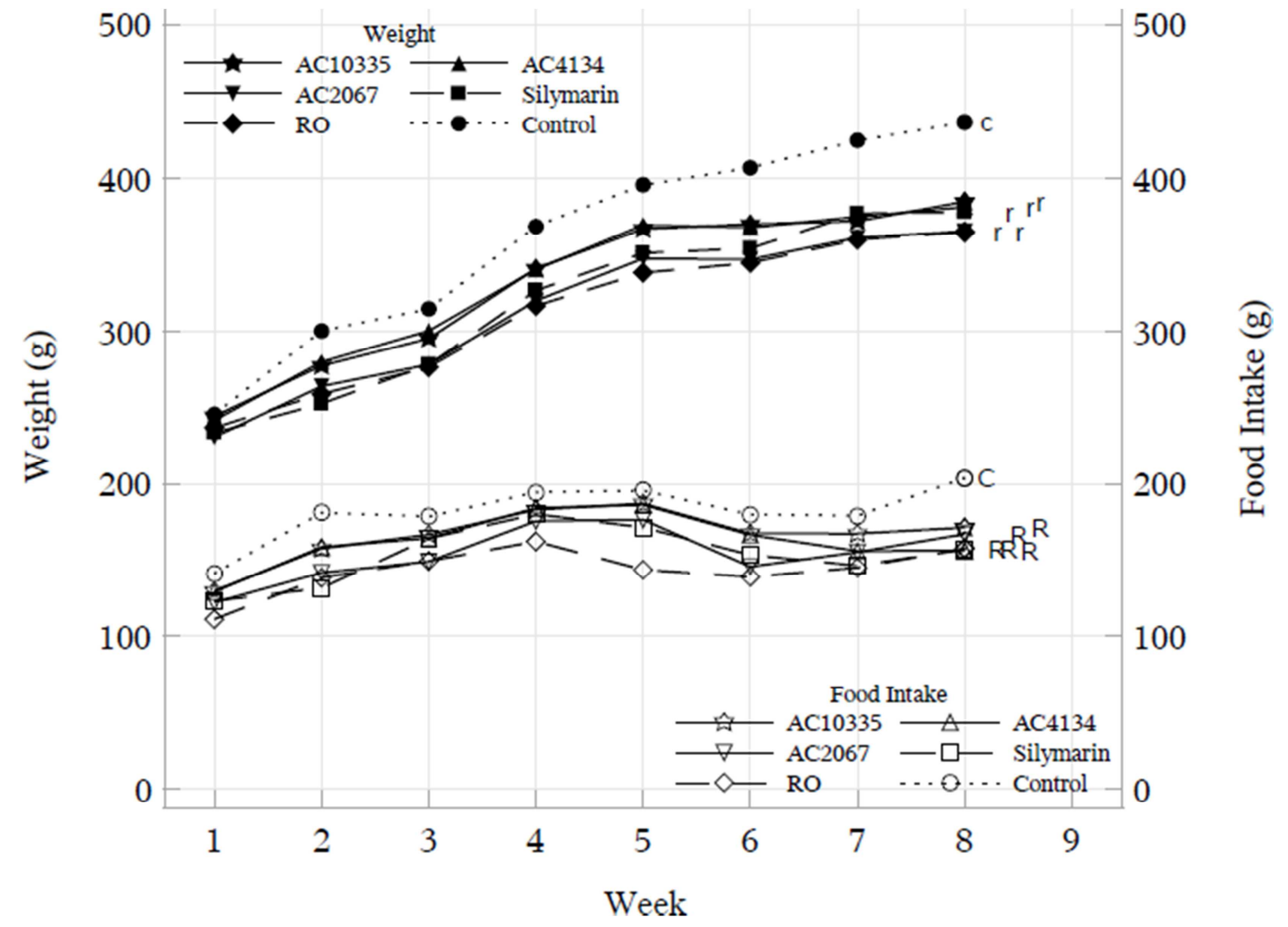

Figure 1. Body weight and weekly food intake of carbon tetrachloride-induced rats treated for 8 weeks. 


\subsection{Serum Biochemical Assays}

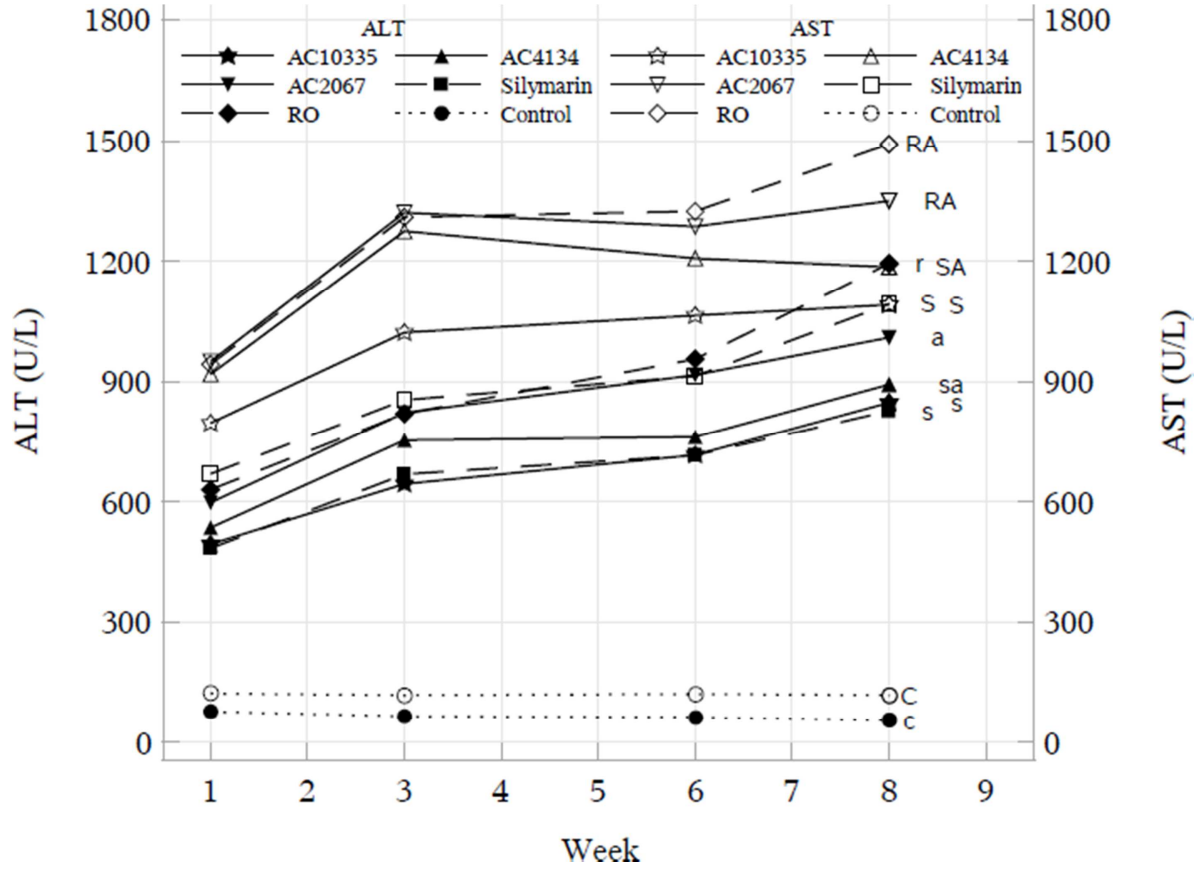

Figure 2. Serum alanine aminotransferase (ALT) and aspartate aminotransferase (AST) activities of carbon tetrachloride-induced rats treated for 8 weeks.

Twenty percent of $\mathrm{CCl}_{4}$ could induce hepatotoxicity, and ALT and AST were $1193.8 \pm 257.3 \mathrm{U} / \mathrm{L}$ and $1491.3 \pm 328.3$ $\mathrm{U} / \mathrm{L}$ in the RO group at the $8^{\text {th }}$ week, respectively. Treatment with the dose of $413.4 \mathrm{mg} / \mathrm{kg}$ BW A.cinnamomea every day significantly reduced ALT and AST levels to 892.5 \pm 120.6
$\mathrm{U} / \mathrm{L}$ and $1185.3 \pm 264.5 \mathrm{U} / \mathrm{L}$, respectively (Figure 2). However, there were no significant difference for total protein, albumin, globulin, triglyceride, and total cholesterol in the serum among the groups administered $20 \% \mathrm{CCl}_{4}$ for 8 weeks (Figure 3).

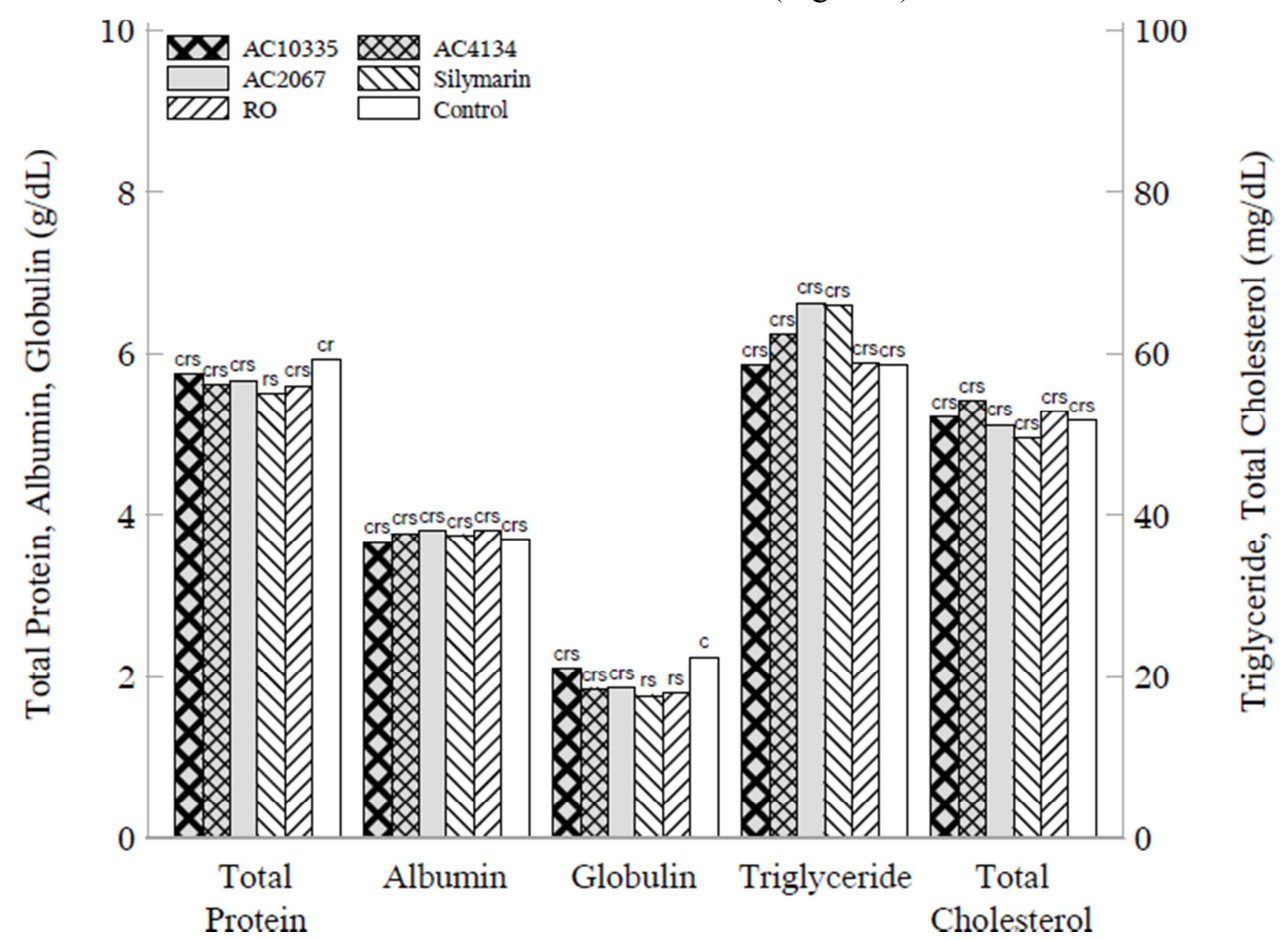

Figure 3. Total protein, albumin, globulin, triglyceride, and total cholesterol of carbon tetrachloride-induced rats after treated for 8 weeks.

\subsection{Biochemical Assays and Histology of Liver}

The liver and spleen were both enlarged after administration of $20 \% \mathrm{CCl}_{4}$ for 8 weeks. The liver weight and spleen weight were $13.8 \pm 2.5 \mathrm{~g}$ and $1.31 \pm 0.26 \mathrm{~g}$ in the RO group, respectively, while they were $10.4 \pm 1.0 \mathrm{~g}$ and $0.75 \pm 0.14 \mathrm{~g}$ in 
the Control group, respectively. The dose of $413.4 \mathrm{mg} / \mathrm{kg} \mathrm{BW}$ A.cinnamomea reduced the spleen size and liver size, and so did

the dose of $1033.5 \mathrm{mg} / \mathrm{kg} \mathrm{BW}$ A.cinnamomea (Figure 4).

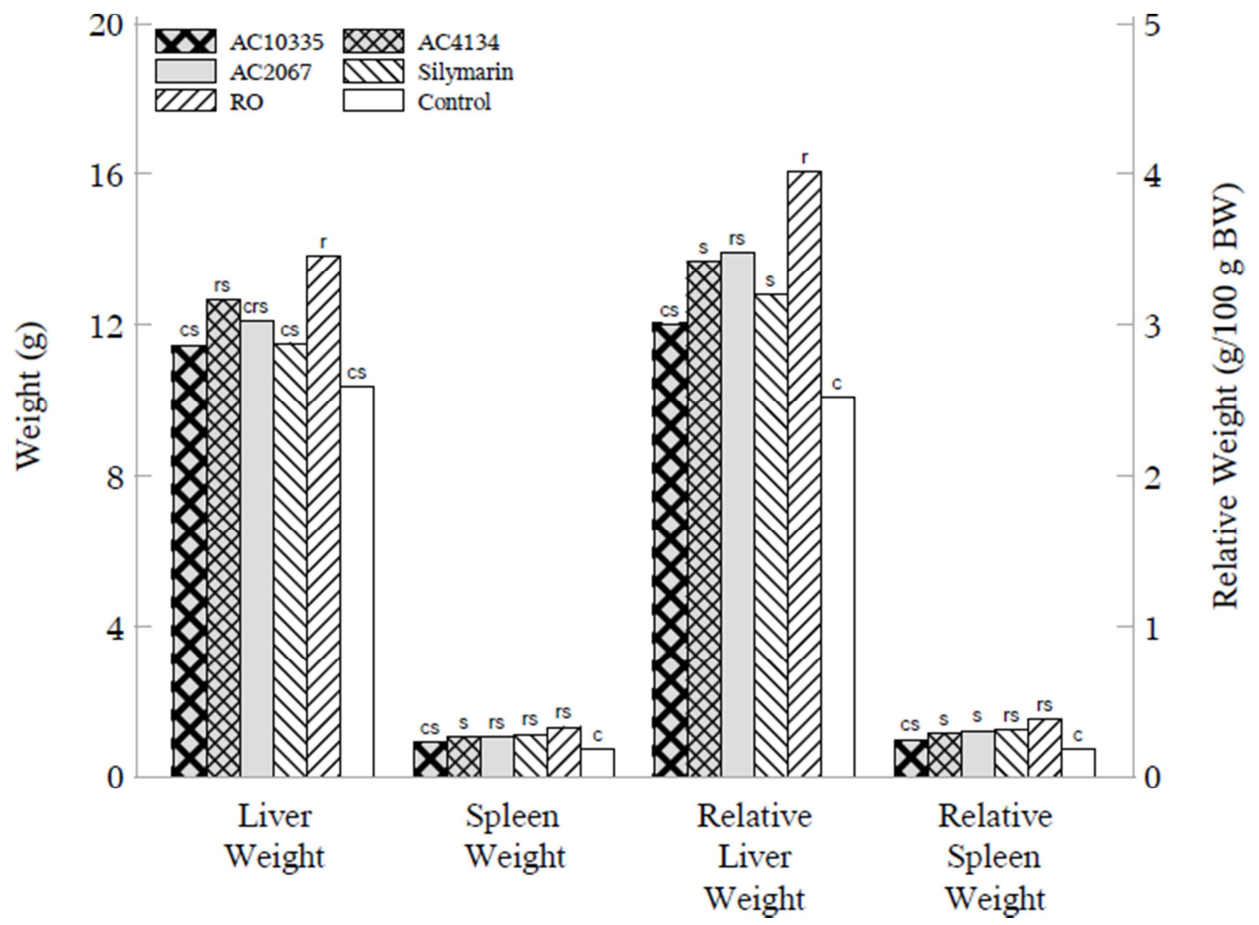

Figure 4. Liver weight, spleen weight, and their relative weights of carbon tetrachloride-induced rats after treated for 8 weeks.

Table 1. Activities of antioxidants in liver of carbon tetrachloride-induced rats after treated for 8 weeks.

\begin{tabular}{lllllll}
\hline Antioxidants & Control & RO & Silymarin & AC2067 & AC4134 & AC10335 \\
\hline SOD (U/mg protein) & $212.6 \pm 7.8 \mathrm{c}$ & $140.9 \pm 26.2 \mathrm{r}$ & $168.6 \pm 15.6 \mathrm{~s}$ & $143.1 \pm 17.5 \mathrm{r}$ & $159.5 \pm 24.6 \mathrm{rs}$ & $177.7 \pm 19.9 \mathrm{~s}$ \\
Catalase (nmol/min/mg protein) & $1542.1 \pm 132.4 \mathrm{cs}$ & $896.5 \pm 257.7 \mathrm{rs}$ & $1225.3 \pm 269.1 \mathrm{crs}$ & $992.2 \pm 278.7 \mathrm{rs}$ & $1051.1 \pm 387.1 \mathrm{rs}$ & $1297.4 \pm 348.0 \mathrm{cs}$ \\
GPx $(\mathrm{mU} / \mathrm{mg}$ protein) & $1610.7 \pm 165.8 \mathrm{c}$ & $893.2 \pm 263.6 \mathrm{rs}$ & $1155.7 \pm 243.4 \mathrm{rs}$ & $986.7 \pm 267.5 \mathrm{rs}$ & $1082.7 \pm 401.6 \mathrm{rs}$ & $1234.2 \pm 348.6 \mathrm{~s}$ \\
GRd $(\mathrm{mU} / \mathrm{mg}$ protein) & $17.6 \pm 1.9 \mathrm{cs}$ & $12.9 \pm 2.6 \mathrm{rs}$ & $15.7 \pm 3.7 \mathrm{crs}$ & $12.2 \pm 2.3 \mathrm{r}$ & $14.8 \pm 3.5 \mathrm{crs}$ & $16.4 \pm 1.8 \mathrm{cs}$ \\
GSH $(\mu \mathrm{mol} / \mathrm{mg}$ tissue) & $16.2 \pm 1.9 \mathrm{c}$ & $5.1 \pm 1.8 \mathrm{r}$ & $8.4 \pm 2.1 \mathrm{~s}$ & $5.1 \pm 3.0 \mathrm{r}$ & $7.7 \pm 2.4 \mathrm{rs}$ & $8.6 \pm 2.4 \mathrm{~s}$ \\
\hline
\end{tabular}

The same letter indicated no significant difference ( $p>0.05)$ compared with the Control $(c), R O(r)$, or Silymarin (s) groups for Dunnett's test, respectively.

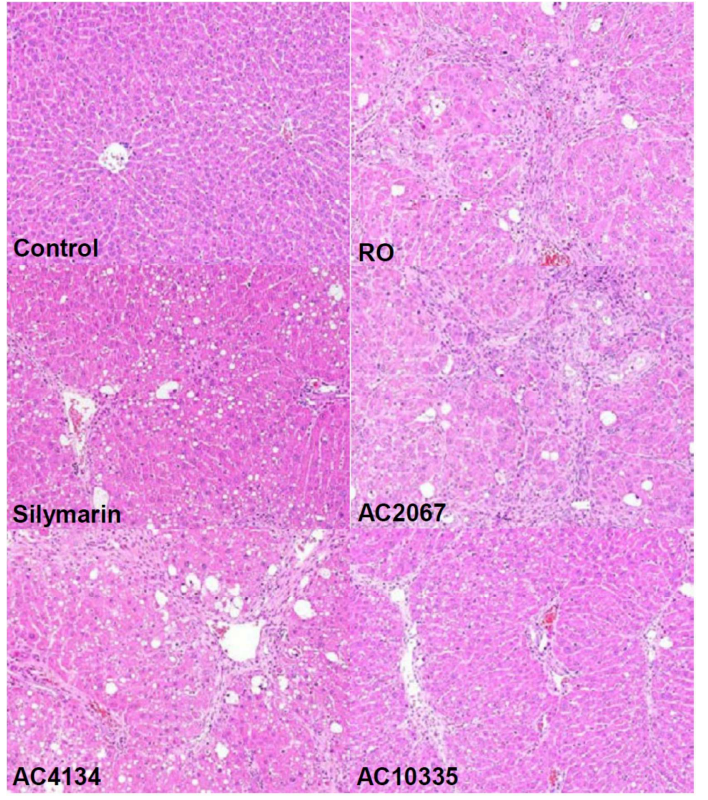

Figure 5. Liver histology observed by hematoxylin and eosin (H\&E) staining at 200x magnification in carbon tetrachloride-induced rats after treated for 8 weeks.
After administration of $20 \% \mathrm{CCl}_{4}$ for 8 weeks, activities of SOD, catalase, GPx, GRd, and GSH in the liver were all significantly decreased. The dose of $1033.5 \mathrm{mg} / \mathrm{kg} \mathrm{BW}$ A.cinnamomea could increase the activities of SOD (177.7 \pm $19.9 \mathrm{U} / \mathrm{mg}$ protein), GPx (1234.2 $\pm 348.6 \mathrm{mU} / \mathrm{mg}$ protein), and GSH $(8.6 \pm 2.4 \mu \mathrm{mol} / \mathrm{mg}$ tissue $)$, and could recover the activities of catalase $(1297.4 \pm 348.0 \mathrm{nmol} / \mathrm{min} / \mathrm{mg}$ protein $)$ and GRd (16.4 $\pm 1.8 \mathrm{mU} / \mathrm{mg}$ protein) (Table 1$)$.

The liver histology in the RO group showed slight to severe vacuolation, enlarged liver cell, necrosis, liver cell regeneration, bile duct recanalization (Figure 5). The average scores of vacuolation and necrosis were $2.1 \pm 1.0$ and $2.0 \pm$ 0.5 , respectively (Table 2 ). Slight and severe liver fibrosis was revealed in the RO group, and thick interconnecting septa could be observed (Figure 6). The average score of fibrosis was $3.6 \pm 0.7$ (Table 2). Treatment with $20 \mathrm{mg} / \mathrm{mL}$ silymarin and $206.7-1033.5 \mathrm{mg} / \mathrm{kg}$ BW A.cinnamomea could not reduce liver vacuolation and necrosis after administration of $20 \% \mathrm{CCl}_{4}$ for 8 weeks, but silymarin and $1033.5 \mathrm{mg} / \mathrm{kg} \mathrm{BW}$ A.cinnamomea could reduce liver fibrosis, $2.4 \pm 1.1$ and $2.3 \pm$ 0.9 , respectively. Hydroxyproline in the liver was also significantly increased $(79.1 \pm 15.9 \mu \mathrm{g} / 100 \mathrm{~g}$ tissue $)$ after 
administration of $20 \% \mathrm{CCl}_{4}$ for 8 weeks, and treatment with $20 \mathrm{mg} / \mathrm{mL}$ silymarin and $1033.5 \mathrm{mg} / \mathrm{kg}$ BW A.cinnamomea also significantly reduced the hydroxyproline in the liver, 52.8 $\pm 12.5 \mu \mathrm{g} / 100 \mathrm{~g}$ tissue and $56.2 \pm 9.3 \mu \mathrm{g} / 100 \mathrm{~g}$ tissue, respectively (Table 2 ).

Table 2. Liver assessment of carbon tetrachloride-induced rats after treated for 8 weeks.

\begin{tabular}{|c|c|c|c|c|c|c|}
\hline Liver assessment & Control & RO & Silymarin & AC2067 & AC4134 & $\mathbf{A C 1 0 3 3 5}$ \\
\hline Vacuolation & $0.0 \pm 0.0 \mathrm{c}$ & $2.1 \pm 1.0 \mathrm{rs}$ & $2.4 \pm 0.7 \mathrm{rs}$ & $1.6 \pm 0.5 \mathrm{r}$ & $1.7 \pm 0.7 \mathrm{rs}$ & $2.2 \pm 0.8 \mathrm{rs}$ \\
\hline Necrosis & $0.0 \pm 0.0 \mathrm{c}$ & $2.0 \pm 0.5 \mathrm{rs}$ & $1.6 \pm 0.7 \mathrm{rs}$ & $1.8 \pm 0.6 \mathrm{rs}$ & $1.6 \pm 0.5 \mathrm{rs}$ & $1.7 \pm 0.5 \mathrm{rs}$ \\
\hline Fibrosis & $0.0 \pm 0.0 \mathrm{c}$ & $3.6 \pm 0.7 \mathrm{r}$ & $2.4 \pm 1.1 \mathrm{~s}$ & $3.4 \pm 0.8 \mathrm{r}$ & $3.1 \pm 0.7 \mathrm{rs}$ & $2.3 \pm 0.9 \mathrm{~s}$ \\
\hline Hydroxyproline ( $\mu \mathrm{g} / 100 \mathrm{~g}$ tissue) & $19.6 \pm 5.8 \mathrm{c}$ & $79.1 \pm 15.9 \mathrm{r}$ & $52.8 \pm 12.5 \mathrm{~s}$ & $72.7 \pm 18.4 \mathrm{r}$ & $64.7 \pm 16.2 \mathrm{rs}$ & $56.2 \pm 9.3 \mathrm{~s}$ \\
\hline
\end{tabular}

The same letter indicated no significant difference $(p>0.05)$ compared with the Control $(c)$, RO (r), or Silymarin (s) groups for Dunnett's test, respectively.

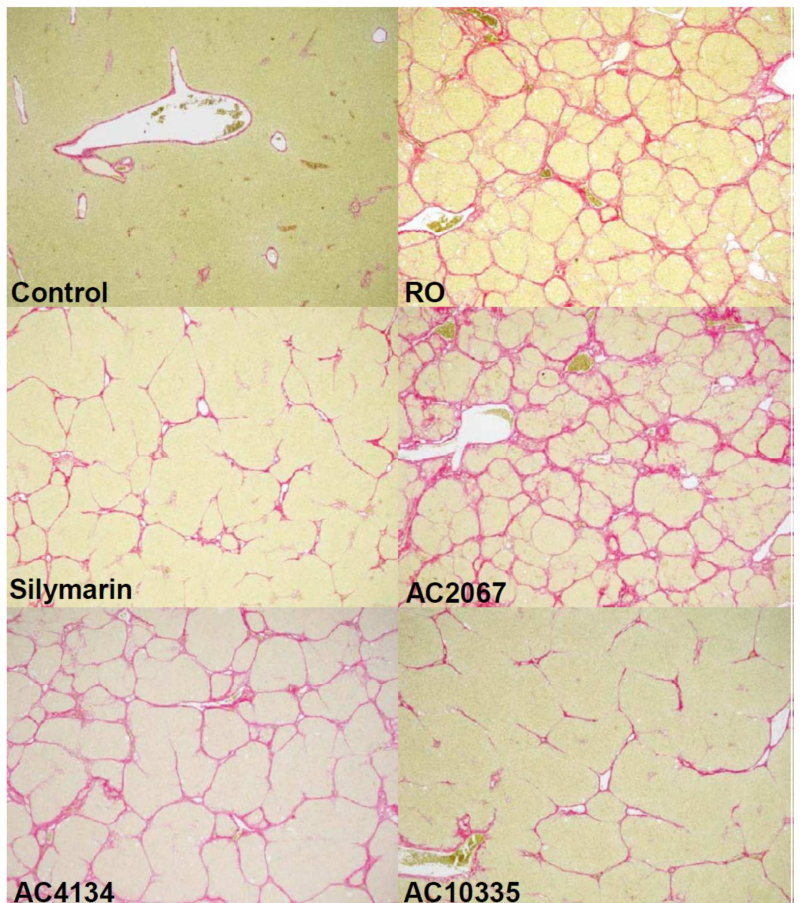

Figure 6. Liver fibrosis observed by sirius red staining at $40 x$ magnification in carbon tetrachloride-induced rats after treated for 8 weeks.

\section{Discussion}

The activities of ALT and AST were relatively high in a normal adult liver tissue homogenate, 44000 and $142000 \mathrm{U} / \mathrm{g}$ wet tissue homogenate, respectively, while their activities in serum were only 16 and $20 \mathrm{U} / g$ wet tissue homogenate, respectively [17]. In Sprague Dawley rats, reference values of ALT and AST were $44 \pm 1$ and $106 \pm 1 \mathrm{U} / \mathrm{L}$, respectively [18] When liver got damaged, it would lead to releases of ALT and AST from damaged liver cells into bloodstreams and result in impressively elevated levels of ALT and AST in serum [17]. The carbon tetrachloride-induced elevated levels of ALT and AST were significantly reduced when administration of the A.cinnamomea product at 413.4 and $1033.5 \mathrm{mg} / \mathrm{kg} \mathrm{BW}$ for 8 weeks, while those levels were significantly reduced when administration of wheat-based solid-state fermented A.cinnamomea at doses greater than or equal to $540 \mathrm{mg} / \mathrm{kg}$ BW [19], or administration of A.cinnamomea at $3150 \mathrm{mg} / \mathrm{kg}$ BW [20].

De Ritis, et al. indicated that abnormally elevated levels of ALT and AST combined with AST/ALT ratio could be a sensitive index of an activity of a liver disease [21]. Lower AST/ALT ratios were found in viral hepatitis [21-24], drug-induced liver injury [25, 26], and metabolic syndrome [27], but higher AST/ALT ratios were found in cholestasis [21], nonalcoholic fatty liver disorder [23], liver cirrhosis [22, 24, 28], and even alcoholic liver disorder [23, 24, 29]. For carbon tetrachloride-induced hepatotoxicity, the AST/ALT ratio decreased (1.09-1.16) while compared with control group (1.79-1.88) [19, 20], and so did it in the study (1.25). Administration of A.cinnamomea or silymarin would not markedly affect the AST/ALT ratio (0.91-1.32) [19, 20] because the levels of ALT and AST recovered in the same direction. However, the level of ALT was sustainably elevated with the increase of treating time (Figure 2). It might suggest that the liver continuously got hurt.

Sustained liver injury would lead to hepatic stellate cells activating and transdifferentiating from quiescent cells into proliferative, fibrogenic, and contractile myofibroblasts, that resulted in accumulation of abundant fibril-forming extracellular matrix [30] and an elevated level of hydroxyproline [31]. With proper treatment, liver fibrosis would be reversible [32]. The study showed that the level of hydroxyproline and the score of fibrosis significantly decreased to $56.2 \pm 9.3 \mu \mathrm{g} / 100 \mathrm{~g}$ tissue and $2.3 \pm 0.9$ when administration of the A.cinnamomea product at $1033.5 \mathrm{mg} / \mathrm{kg}$ BW for 8 weeks, respectively, while the level of hydroxyproline and the score of fibrosis were $79.1 \pm 15.9$ $\mu \mathrm{g} / 100 \mathrm{~g}$ tissue and $3.6 \pm 0.7$ at control group, respectively (Table 2). Significantly decreased level of hydroxyproline also existed in previous studies when administration of wheat-based solid-state fermented A.cinnamomea at dose of $1080 \mathrm{mg} / \mathrm{kg} \mathrm{BW}$ [19] and administration of A.cinnamomea at $1400 \mathrm{mg} / \mathrm{kg} \mathrm{BW}$ [20]. It suggested that the improvement of liver fibrosis just happened at administration of A.cinnamomea at a dose of higher than $1000 \mathrm{mg} / \mathrm{kg} \mathrm{BW}$.

On top of that, administration of A.cinnamomea could increase activities of superoxide dismutase, catalase, glutathione peroxidase and reduce malondialdehyde levels, the end-product of lipid peroxidation [33, 34], and even the reduced activities of superoxide dismutase, catalase, glutathione peroxidase, glutathione reductase, and glutathione were recovered when administration of the A.cinnamomea product at $1033.5 \mathrm{mg} / \mathrm{kg} \mathrm{BW}$ for 8 weeks (Table 1). However, activities of superoxide dismutase, catalase, glutathione peroxidase, and glutathione were not recovered in rats with administration of wheat-based 
solid-state fermented A.cinnamomea even at dose of 1080 $\mathrm{mg} / \mathrm{kg} \mathrm{BW}$ [19]. Activities of superoxide dismutase and glutathione peroxidase were also not recovered in rats with administration of A.cinnamomea even at $3150 \mathrm{mg} / \mathrm{kg} \mathrm{BW}$ [20]. It was confirmed that carbon tetrachloride would induce oxidative stress, leading to membrane steatosis and lipid peroxidation [35], and could result in marked reduction in the activities of glutathione peroxidase, glutathione reductase, glutathione, superoxide dismutase, catalase either in liver or in brain [36]. Conversely, the reduced activities of the antioxidants lost sufficient capacity of neutralizing free radicals. It might be the reason why wheat-based solid-state fermented A.cinnamomea at a dose of lower than $500 \mathrm{mg} / \mathrm{kg}$ BW could not sufficiently reduce the elevated levels of ALT and AST [19, 20].

With the novel process, the cost of the A.cinnamomea product was lowered, but it provided even more effective hepatoprotection than those by other means to people with chronic liver diseases. A.cinnamomea as a traditional Chinese medicine or a healthy food would be more easily promoted. However, for health promotion, integration of businesses, governments, social organizations, and medical institutions would be needed [37].

\section{Conclusion}

The results indicated that the novel process was effective and successful. In the past, people with liver problems wanted more effective A.cinnamomea products but couldn't afford them. The novel process to combine A.cinnamomea mycelia extracts with fruiting bodies would make high quality and low price A.cinnamomea products possible. However, the study only focused on the hepatoprotection. For other medical effects, whether the A.cinnamomea product via the novel process would be also effective was still unknown, and more studies should be conducted in the future.

\section{References}

[1] A. J. Hsiao, L. H. Chen, and T. H. Lu, "Ten leading causes of death in Taiwan: A comparison of two grouping lists," J. Formos. Med. Assoc., vol. 114, no. 8, pp. 679-680, 2015.

[2] C. J. L. Murray, T. Vos, R. Lozano, M. Naghavi, A. D. Flaxman, C. Michaud, M. Ezzati, K. Shibuya, J. A. Salomon, S. Abdalla et al., "Disability-adjusted life years (DALYs) for 291 diseases and injuries in 21 regions, 1990-2010: A systematic analysis for the Global Burden of Disease Study 2010," Lancet, vol. 380, no. 9859 , pp. 2197-2223, 2012/12/15/, 2012.

[3] A. A. Mokdad, A. D. Lopez, S. Shahraz, R. Lozano, A. H. Mokdad, J. Stanaway, C. J. L. Murray, and M. Naghavi, "Liver cirrhosis mortality in 187 countries between 1980 and 2010: A systematic analysis," BMC Med., vol. 12, no. 1, pp. 145, 2014.

[4] J. Wiegand, and T. Berg, "The etiology, diagnosis and prevention of liver cirrhosis,” Dtsch. Ärztebl. Int., vol. 110, no. 6, pp. 85-91, 2013.

[5] P. E. Chang, G. W. Wong, J. W. Q. Li, H. F. Lui, W. C. Chow, and C. K. Tan, "Epidemiology and clinical evolution of liver cirrhosis in Singapore," Ann. Acad. Med. Singapore, vol. 44, no. 6, pp. 218-225, 2015.

[6] P. L. Gonçalves, M. d. P. Zago-Gomes, C. C. Marques, A. T. Mendonça, C. S. Gonçalves, and F. E. L. Pereira, "Etiology of liver cirrhosis in Brazil: Chronic alcoholism and hepatitis viruses in liver cirrhosis diagnosed in the state of Espírito Santo," Clinics, vol. 68, no. 3, pp. 291-295, 2013.

[7] Z. H. Ao, Z. H. Xu, Z. M. Lu, H. Y. Xu, X. M. Zhang, and W. F. Dou, "Niuchangchih (Antrodia camphorata) and its potential in treating liver diseases," J. Ethnopharmacol., vol. 121, no. 2, pp. 194-212, 2009.

[8] C. Y. Chang, Z. N. Huang, H. H. Yu, L. H. Chang, S. L. Li, Y. P. Chen, K. Y. Lee, and J. J. Chuu, "The adjuvant effects of Antrodia camphorata extracts combined with anti-tumor agents on multidrug resistant human hepatoma cells," J. Ethnopharmacol., vol. 118, no. 3, pp. 387-395, 2008.

[9] F. C. Yang, Y. H. Yang, and H. C. Lu, "Enhanced antioxidant and antitumor activities of Antrodia cinnamomea cultured with cereal substrates in solid state fermentation," Biochem. Eng. J., vol. 78, pp. 108-113, 2013.

[10] D. Z. Liu, H. J. Liang, C. H. Chen, C. H. Su, T. H. Lee, C. T. Huang, W. C. Hou, S. Y. Lin, W. B. Zhong, P. J. Lin et al., "Comparative anti-inflammatory characterization of wild fruiting body, liquid-state fermentation, and solid-state culture of Taiwanofungus camphoratus in microglia and the mechanism of its action," J. Ethnopharmacol., vol. 113, no. 1, pp. 45-53, 2007.

[11] C. H. Chang, H. E. Wang, P. Y. Liaw, C. C. Peng, and R. Y. Peng, "Antrodia cinnamomea exhibits a potent neuroprotective effect in the PC12 cell-A $\beta_{25-35}$ model - pharmacologically through adenosine receptors and mitochondrial pathway," Planta Med., vol. 78, no. 17, pp. 1813-1823, 2012.

[12] E. Xia, G. Rao, H. van Remmen, A. R. Heydari, and A. Richardson, "Activities of antioxidant enzymes in various tissues of male Fischer 344 rats are altered by food restriction," J. Nutr., vol. 125, no. 2, pp. 195-201, 1995.

[13] H. Aebi, "Catalase in vitro," Methods Enzymol., vol. 105, pp. 121-126, 1984.

[14] P. J. Hissin, and R. Hilf, "A fluorometric method for determination of oxidized and reduced glutathione in tissues," Anal. Biochem., vol. 74, no. 1, pp. 214-226, 1976.

[15] R. E. Neuman, and M. A. Logan, "The determination of hydroxyproline,” J. Biol. Chem., vol. 184, pp. 299-306, 1950.

[16] G. Boigk, L. Stroedter, H. Herbst, J. Waldschmidt, E. O. Riecken, and D. Schuppan, "Silymarin retards collagen accumulation in early and advanced biliary fibrosis secondary to complete bile duct obliteration in rats," Hepatology, vol. 26, no. 3, pp. 643-649, 1997.

[17] F. Wróblewski, and J. S. LaDue, "Serum glutamic pyruvic transaminase (SGP-T) in hepatic disease: A preliminary report," Ann. Intern. Med., vol. 45, no. 5, pp. 801-811, 1956.

[18] T. Matsuzawa, Y. Hayashi, M. Nomura, T. Unno, T. Igarashi, T. Furuya, K. Sekita, A. Ono, Y. Kurokawa, and Y. Hayashi, "A survey of the values of clinical chemistry parameters obtained for a common rat blood sample in ninety-eighty Japanese laboratories," J. Toxicol. Sci., vol. 22, no. 1, pp. 25-45, 1997. 
[19] H. W. Chiu, and K. F. Hua, "Hepatoprotective effect of wheat-based solid-state fermented Antrodia cinnamomea in carbon tetrachloride-induced liver injury in rat," PLoS ONE, vol. 11, no. 4, pp. e0153087, 2016.

[20] Y. L. Shih, M. F. Wu, C. H. Lee, M. Y. Yeh, J. Chou, J. Y. Liu, H F. Lu, Y. P. Huang, N. C. Liao, and J. G. Chung, "Antrodia cinnamomea reduces carbon tetrachloride-induced hepatotoxicity in male Wister rats," In Vivo, vol. 31, pp. 877-884, 2017.

[21] F. de Ritis, G. Giusti, F. Piccinino, and L. Cacciatore, "Biochemical laboratory tests in viral hepatitis and other hepatic diseases: Evaluation and follow-up," Bull. World Health Organ., vol. 32, no. 1, pp. 59-72, 1965.

[22] A. L. B. Williams, and J. H. Hoofnagle, "Ratio of serum aspartate to alanine aminotransferase in chronic hepatitis: Relationship to cirrhosis," Gastroenterology, vol. 95, no. 3, pp. 734-739, 1988.

[23] K. S. Parmar, G. K. Singh, G. P. Gupta, T. Pathak, and S. Nayak, "Evaluation of de Ritis ratio in liver-associated diseases," Int. J. Med. Sci. Public Health, vol. 5, no. 9, pp. 1783-1788, 2016.

[24] M. A. Hyder, M. Hasan, and A. H. Mohieldein, "Comparative levels of ALT, AST, ALP and GGT in liver associated diseases," Euro. J. Exp. Bio., vol. 3, no. 2, pp. 280-284, 2013.

[25] B. M. Lee, W. C. Lee, J. Y. Jang, P. Ahn, J. N. Kim, S. W. Jeong, E. J. Park, S. H. Lee, S. G. Kim, S. W. Cha et al., "Clinical features of drug-induced liver injury according to etiology," J. Korean Med. Sci., vol. 30, pp. 1815-1820, 2015.

[26] E. Björnsson, and R. Olsson, "Outcome and prognostic markers in severe drug-induced liver disease," Hepatology, vol. 42, no. 2, pp. 481-489, 2005.

[27] P. Deepa, and N. Sasivathanam, "A study of AST/ALT ratio in metabolic syndrome,” Int. J. Contemp. Med. Res., vol. 4, no. 1, pp. 28-30, 2017.

[28] E. Giannini, D. Risso, F. Botta, B. Chiarbonello, A. Fasoli, F. Malfatti, P. Romagnoli, E. Testa, P. Ceppa, and R. Testa, "Validity and clinical utility of the aspartate aminotransferase-alanine aminotransferase ratio in assessing disease severity and prognosis in patients with hepatitis $\mathrm{C}$ virus-related chronic liver disease," Arch. Intern. Med., vol. 163, no. 2, pp. 218-224, 2003.

[29] P. S. Alves, E. A. Camilo, and J. P. Correia, "The SGOT/SGPT ratio in alcoholic liver disease," Acta Méd. Port., vol. 3, no. 4, pp. 255-260, 1981.

[30] S. L. Friedman, "Molecular regulation of hepatic fibrosis, an integrated cellular response to tissue injury," J. Biol. Chem., vol. 275 , no. 4 , pp. $2247-2250,2000$.

[31] R. A. Pierce, M. R. Glaug, R. S. Greco, J. W. Mackenzie, C. D. Boyd, and S. B. Deak, "Increased procollagen mRNA levels in carbon tetrachloride-induced liver fibrosis in rats," J. Biol. Chem., vol. 262, no. 4, pp. 1652-1658, 1987.

[32] R. C. Benyon, and J. P. Iredale, "Is liver fibrosis reversible?," Gut, vol. 46, no. 4, pp. 443-446, 2000.

[33] M. M. Shiu, B. Y. Huang, C. C. Liu, C. S. Liao, and M. C. Lin, "Protective effect of Antrodia camphorate on the tissues of brain, kidney, lung, and the liver is correlated with declining lipid peroxidation,” Am. J. Lab. Med., vol. 3, no. 1, pp. 6-10, 2018.

[34] B. Y. Huang, C. C. Liu, Z. Y. Jian, and M. C. Lin, “Antrodia camphorata declines oxidative stress and enhances antioxidant enzyme activity in the brain cortex of rats," Am. J. Lab. Med., vol. 1, no. 3, pp. 29-33, 2016.

[35] M. Boll, L. W. D. Weber, E. Becker, and A. Stampfl, "Mechanism of carbon tetrachloride-induced hepatotoxicity. Hepatocellular damage by reactive carbon tetrachloride metabolites," Z. Naturforsch., vol. 56C, no. 7-8, pp. 649-659, 2001.

[36] K. R. Ritesh, A. Suganya, H. V. Dileepkumar, Y. Rajashekar, and T. Shivanandappa, "A single acute hepatotoxic dose of $\mathrm{CCl}_{4}$ causes oxidative stress in the rat brain," Toxicol. Rep., vol. 2, pp. 891-895, 2015.

[37] J. L. Shen, Q. Wang, Y. Zhang, and H. Y. Ma, "Discussion on the use of Chinese medicine and institutional innovation in community health management," Sci. J. Public Health, vol. 4, no. 3, pp. 235-240, 2016. 